\title{
Understanding anti-IgLON5 disease
}

\section{OPEN}

Francesc Graus, MD,

$\mathrm{PhD}$

Joan Santamaría, MD, $\mathrm{PhD}$

Correspondence to

Dr. Graus:

fgraus@clinic.ub.es

Neurol Neuroimmunol Neuroinflamm

2017;4:e393; doi: 10.1212/ NXI.0000000000000393
The unambiguous characterization of antibodies against neural antigens has been critical to understand the interplay between the immune system and the brain, allowing in some instances the discovery of clinical entities that had been previously unrecognized or lumped with other syndromes under generic names. ${ }^{1}$ The best example is anti-NMDA receptor encephalitis, a relatively common disease that before the discovery of NMDA receptor antibodies was unrecognized or defined with nonspecific terms, such as non-herpetic encephalitis, or confused with Hashimoto encephalopathy or encephalitis lethargica. ${ }^{2}$ A similar scenario applies to anti-IgLON5 disease in which the identification of antibodies against IgLON5, a neural cell adhesion molecule of unknown function, has led to the characterization of a new disorder. ${ }^{3}$ Before the discovery of IgLON5 antibodies, the disease of these patients was defined with descriptive terms or labeled as "atypical early progressive supranuclear palsy (PSP)" or "brainstem tauopathy"(for review, see reference 4), indicating that it could not be classified among well-defined CNS disorders. However, the comprehensive evaluation of the initial patients with IgLON5 antibodies disclosed a common clinical core of symptoms that included a complex sleep disorder with abnormal behaviors and vocalizations during non-REM and REM sleep along with sleep-disordered breathing, gait instability, more typical of disequilibrium than cerebellar ataxia, and bulbar symptoms such as stridor, dysphagia, or central hypoventilation. ${ }^{3}$ These symptoms were found to evolve over months to years, and unlike other CNS disorders associated with antibodies against neural surface antigens, patients with IgLON5 disease did not respond to common immunotherapies. With the identification of more patients, 4 clinical presentations were characterized according to predominant symptoms: prominent sleep disorder, progressive bulbar dysfunction, gait instability with abnormal eye movements reminiscent, but not typical of PSP, and cognitive deterioration sometimes associated with chorea. Independently of the form of presentation, most patients described a sleep disorder when directly questioned about symptoms of sleep apnea and other alterations of sleep or when they were studied with video-polysomnography (V-PSG). ${ }^{5}$

One potential bias of these initial studies is that they emphasized the sleep dysfunction, and therefore, patients could have been selected for IgLON5 antibody screening. Recently, the article by Honorat et al. ${ }^{6}$ published in this issue of Neurology ${ }^{\circledR}$ Neuroimmunology and Neuroinflammation contributes to clarify this issue. These authors re-examined 367 archived serum or CSF samples that showed a pattern of mice brain immunostaining similar to that reported for IgLON5. ${ }^{3}$ Most of the samples had been sent for antibody testing before the discovery of IgLON5 antibodies. Using a commercial cell-based assay, they eventually found that 26 of the samples had IgLON5 antibodies. For 20 of these patients, clinical information was available, including 15 who had detailed Mayo Clinic records. The findings confirmed that brainstem and sleep disorders are the predominant manifestations of anti-IgLON5 disease. Twelve of 15 patients developed sleep dysfunction, mainly sleep apnea. The frequency of abnormal movement and behaviors was lower, but most of the patients were not assessed by V-PSG, which in our experience is critical for full assessment of this disease. In addition, 14/20 (70\%) patients showed gait instability and 12 dysphagia or stridor. Unlike previous series, 7 (35\%) patients had symptoms of central or peripheral nervous system hyperexcitability, including hyperekplexia, fasciculations, cramps, or stiffness. Therefore, this study confirms that the core symptoms of anti-IgLON5 disease include the sleep disorder along with gait instability and bulbar dysfunction and draws attention to investigate for this disease in patients with symptoms that suggest, but are unusual for, stiff-person syndrome spectrum disorder. ${ }^{7}$

From the Neuroimmunology Program (F.G.), August Pi Sunyer Biomedical Research Institute (IDIBAPS); and Service of Neurology (F.G., J.S.) and Multidisciplinary Sleep Disorders Unit (J.S.), Hospital Clínic, Barcelona, Spain.

Funding information and disclosures are provided at the end of the article. Go to Neurology.org/nn for full disclosure forms. The Article Processing Charge was funded by Neurology: Neuroimmunology \& Neuroinflammation.

This is an open access article distributed under the terms of the Creative Commons Attribution-NonCommercial-NoDerivatives License 4.0 (CC BY-NC-ND), which permits downloading and sharing the work provided it is properly cited. The work cannot be changed in any way or used commercially without permission from the journal. 
An intriguing aspect of anti-IgLON5 disease is the concurrence of features suggesting an autoimmune disorder (antibodies against a neuronal surface antigen and a robust association with the HLADRB1*10:01 genotype) and pathologic evidence of a novel neuronal $3 \mathrm{R}+4 \mathrm{R}$ tauopathy mainly involving the brainstem and hypothalamus. ${ }^{4}$ This puzzling scenario challenges current concepts about the pathophysiology of autoimmune and neurodegenerative disorders. One possibility is that the neuronalspecific tau accumulation could be antibody mediated, leading to neuronal dysfunction and ultimately neurodegeneration. ${ }^{8}$ In this scenario, early diagnosis and treatment would be crucial to prevent irreversible neuronal damage. The patients described in initial studies did not improve with immunotherapy, but there was a substantial delay (median, 2 years) between symptom onset and diagnosis. ${ }^{5}$ The retro-
The field of neurologic sciences is wide and expanding, and the management of patients with neurologic disorders has driven to the development of multiple neurologic subspecialties, "Autoimmune Neurology" one of the youngest. Specialization is inevitable, but it should not lead to fragmentation of knowledge or tight boundaries; anti-IgLON5 disease is a perfect example that cross-talk between subspecialties is critical to address complex neurologic diseases and, above all, that a solid neurologic background is the key to unlock puzzling clinical scenarios.

\section{AUTHOR CONTRIBUTIONS}

Francesc Graus: drafting/revising the manuscript, study concept or design, and study supervision. Joan Santamaría: drafting/revising the manuscript.

\section{STUDY FUNDING}

No targeted funding reported.

\section{DISCLOSURE}

F. Graus is on the editorial board for Lancet Neurology, receives royalties, and holds a patent for IgLON5 as a diagnostic test. J. Santamaría received research support from Fundacio La Marato TV3. Go to Neurology.org/nn for full disclosure forms.

\section{REFERENCES}

1. Dalmau J, Geis C, Graus F. Autoantibodies to synaptic receptors and neuronal cell surface proteins in autoimmune diseases of the central nervous system. Physiol Rev 2017;97:839-887.

2. Tan A, Shuey N, Bladin C. A modern perspective on the differential diagnosis between encephalitis lethargica or anti-NMDA-receptor encephalitis. J Clin Neurosci 2010; 17:1204-1206.

3. Sabater L, Gaig C, Gelpi E, et al. A novel non-rapid-eye movement and rapid-eye-movement parasomnia with sleep breathing disorder associated with antibodies to IgLON5: a case series, characterisation of the antigen, and post-mortem study. Lancet Neurol 2014;13:575-586.

4. Gelpi E, Höftberger R, Graus F, et al. Neuropathological criteria of anti-IgLON5-related tauopathy. Acta Neuropathol 2016;132:531-543.

5. Gaig C, Graus F, Compta Y, et al. Clinical manifestations of the anti-IgLON5 disease. Neurology 2017;88:1736-1743.

6. Honorat JA, Komorowski L, Josephs KA, et al. IgLON5 antibody: neurological accompaniments and outcomes in 20 patients. Neurol Neuroimmunol Neuroinflamm 2017; 4:e385. doi: 10.1212/NXI.0000000000000385.

7. Martinez-Hernandez E, Ariño H, McKeon A, et al. Clinical and Immunologic investigations in patients with stiff-person spectrum disorder. JAMA Neurol 2016;73: $714-720$

8. Leshchyns'ka I, Sytnyk V. Reciprocal interactions between cell adhesion molecules of the immunoglobulin superfamily and the cytoskeleton in neurons. Front Cell Dev Biol 2016;4:9.

9. Bonello M, Jacob A, Ellul MA, et al. IgLON5 disease responsive to immunotherapy. Neurol Neuroimmunol Neuroinflamm 2017;4:e383. doi: 10.1212/NXI.0000000000000383.

10. Sabater L, Planagumà J, Dalmau J, Graus F. Cellular investigations with human antibodies associated with the anti-IgLON5 syndrome. J Neuroinflammation 2016; $13: 226$. 


\title{
Neurology \\ Neuroimmunology \& Neuroinflammation
}

\author{
Understanding anti-IgLON5 disease \\ Francesc Graus and Joan Santamaría \\ Neurol Neuroimmunol Neuroinflamm 2017;4; \\ DOI 10.1212/NXI.0000000000000393
}

This information is current as of August 24, 2017

Updated Information \& Services

References

Citations

Permissions \& Licensing

Reprints including high resolution figures, can be found at:

http://nn.neurology.org/content/4/5/e393.full.html

This article cites 10 articles, 0 of which you can access for free at: http://nn.neurology.org/content/4/5/e393.full.html\#\#ref-list-1

This article has been cited by 1 HighWire-hosted articles: http://nn.neurology.org/content/4/5/e393.full.html\#\#otherarticles

Information about reproducing this article in parts (figures,tables) or in its entirety can be found online at: http://nn.neurology.org/misc/about.xhtml\#permissions

Information about ordering reprints can be found online: http://nn.neurology.org/misc/addir.xhtml\#reprintsus

Neurol Neuroimmunol Neuroinflamm is an official journal of the American Academy of Neurology.

Published since April 2014, it is an open-access, online-only, continuous publication journal. Copyright

Copyright (C) 2017 The Author(s). Published by Wolters Kluwer Health, Inc. on behalf of the American Academy of Neurology.. All rights reserved. Online ISSN: 2332-7812.

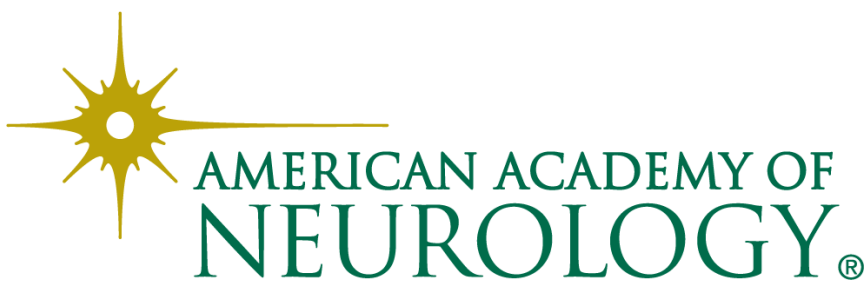

